\title{
ANALISIS PERENCANAAN PAJAK SEBAGAI UPAYA MEMINIMALKAN BEBAN PAJAK DAN MENINGKATKAN KINERJA PERUSAHAAN PADA PT XYZ
}

\author{
Fia Prayola Ahmad \\ fiaprayola@gmail.com \\ Hayati Fatimah \\ amiramdany@gmail.com \\ Nur Hasyim \\ hajinurhasim@gmail.com
}

\author{
Program Studi Akuntansi Keuangan Terapan Politeknik Negeri Jakarta
}

\begin{abstract}
The aim of this researchwas for describing the compliance of tax responsibility, analyzing the tax planning, and analyzing the company performances at PT XYZ if the tax planning was applied. This research was a qualitative research which used PT XYZ's Income Tax in 2018 as the object. Data that used in this research were primary data in the form of interview and also secondary data such as PT XYZ's financial report and fiscal reconciliation report in 2018. The results of this study showed that PT XYZ had fulfilled its tax obligations, such as registering the NPWP and doing the Income Tax Due responsibility such as calculating Income Tax Due of USD 178,018 and Underpaying Income Tax of USD 1,606, paying Income Tax of Rp 22,567,512, and reporting the Income Tax using SPT 1771 - \$. The results were also obtained consisting of a tax reduction of USD 30.720 and appearing an Overpaying Income Tax of USD 29.114 as a result of tax planning such as making a nominative list, paying insurance premiums, turning in-kind assistance into benefits, paying pensions to Pension Funds that have been approved by the Minister of Finance, requesting evidence of official travel payments, conduct research and development activities in Indonesia, and carry out CSR activities in accordance with Law No. 36 of 2008. With this tax planning, there was an increase in current ratio of $0.38 \%$, an increase in cash ratio of $0.006 \%$, and a decrease in the debt ratio of $0,32 \%$.
\end{abstract}

\section{Keywords: Income Tax, Tax Planning, Company Performances}

\begin{abstract}
ABSTRAK
Tujuan dari penelitian ini adalah untuk mendeskripsikan pemenuhan kewajiban perpajakan, menganalisis perencanaan pajak, dan menganalisis kinerja perusahaan PT XYZ setelah penerapan perencanaan pajak. Jenis penelitian ini adalah penelitian kualitatif dengan objek penelitian berupa Pajak Penghasilan (PPh) Badan PT XYZ tahun 2018.Data yang digunakan dalam penelitian ini adalah data primer berupa hasil wawancara serta data sekunder berupa laporan keuangan dan laporan rekonsiliasi fiskal PT XYZ tahun 2018. Hasil dari penelitian ini adalah bahwa PT XYZ telah melaksanakan pemenuhan kewajiban perpajakannya yaitu melakukan pendaftaran NPWP dan melakukan kewajiban PPh Terutang seperti menghitung PPh Terutang sebesar USD 178.018 dan PPh Kurang Bayar sebesar USD 1.606, membayar PPh Terutang sebesar Rp 22.567.512, dan melaporkan PPh Badan menggunakan SPT 1771-\$. Diperoleh juga hasil berupa penurunan beban pajak sebesar USD 30.720 dan kemunculan PPh Lebih Bayar sebesar USD 29.114 sebagai akibat dari perencanaan pajak seperti membuat daftar nominatif, membayar premi asuransi, mengalihkan pemberian natura menjadi tunjangan, membayar pensiun kepada Dana Pensiun yang telah disahkan Menteri Keuangan, meminta bukti-bukti perjalanan dinas, melakukan penelitian dan pengembangan di Indonesia, dan melakukan kegiatan CSR sesuai UU No. 36 Tahun 2008. Adanya perencanaan pajak tersebut mengakibatkan timbulnya peningkatan rasio lancar sebesar $0,38 \%$, peningkatan rasio kas sebesar $0,006 \%$, dan penurunan rasio hutang sebesar $0,32 \%$.
\end{abstract}

Kata kunci: Pajak Penghasilan, Perencanaan Pajak, Kinerja Perusahaan.

\section{PENDAHULUAN \\ Latar Belakang}

Bagi negara, peran pajak sangat penting sebagai sumber dana untuk mengisi

kas negara, tanpa pajak tidak mungkin penyelenggaraan suatu pemerintahan dapat 
dilaksanakan (Lubis, 2009). Hampir semua negara di dunia mengenakan pajak bagi warganya, termasuk Indonesia.

Jika pajak berperan sebagai pemasukan bagi negara, maka tidak bagi perusahaan. Pajak justru menjadi beban yang akan mengurangi nilai laba bersih perusahaan (Hien \& Mariani, 2017). Terdapat perbedaan kepentingan antara Wajib Pajak dengan pemerintah dalam melaksanakan pajak. Setiap Wajib Pajak tentunya memiliki kecenderungan menghindar dari kewajiban membayar pajak sehingga sebisa mungkin membayar pajak pada jumlah sekecil-kecilnya (Faisal, 2009). Di sisi lain, pemerintah membutuhkan dana untuk membiayai penyelenggaraan pemerintahan yang sebagian besar berasal dari pajak. Adanya perbedaan kepentingan ini membuat Wajib Pajak berkeinginan untuk mengurangi pembayaran pajak mereka, termasuk perusahaan.

Hal tersebut bukanlah tidak mungkin untuk dilakukan mengingat saat ini sistem pemungutan pajak yang diimplementasikan di Indonesia ialah self assesment system. Dengan sistem ini, Wajib Pajak boleh menghitung, membayar, dan melaporkan sendiri besarnya pajak yang harus disetor sedangkan fiskus atau pemerintah hanya bertugas untuk mengawasi (Supramono \& Damayanti, 2010). Dengan diimplementasikannya sistem ini, maka Wajib Pajak dapat mempelajari regulasi pajak dan juga cara mengelola pajak supaya tidak memberatkan Wajib Pajak (Pohan, 2013).

Hal tersebut sejalan dengan tujuan utama tax planning yaitu memenuhi kewajiban perpajakan dengan benar dan tidak mengganggu kelangsungan perusahaan (Muljono, 2009). Perencanaan pajak ini tentunya berhubungan dengan laba bersih yang didapatkan perusahaan. Jika beban pajak dapat diminimalkan maka laba perusahaan akan lebih besar. Dalam kerangka kerja konseptual akuntansi disebutkan bahwa informasi mengenai (ukuran) laba perusahaan dapat menjadi dasar untuk memprediksi kinerja perusahaan di masa depan (Hery, 2015). Hery juga menyebutkan bahwa fokus utama pelaporan keuangan adalah informasi mengenai kinerja perusahaan yang diberikan oleh ukuran laba. Jadi, selain untuk meminimalkan beban pajak, perencanaan pajak juga dapat digunakan untuk meningkatkan kinerja perusahaan karena laba bersih perusahaan bertambah besar. Selain itu menurut Saefi, Kesuma, Lahaya (2017), penghematan kas dari akibat penghematan pajak yang dilakukan perusahaan melalui langkah-langkah perencanaan pajak yang sesuai peraturan dan undang-undang perpajakan, telah mampu meningkatkan kinerja perusahaan yang diukur dengan rasio likuiditas dan solvabilitas.

Berdasarkan hasil wawancara, observasi, dan dokumentasi yang penulis lakukan pada PT XYZ diperoleh hasil bahwa perusahaan ini masih belum memaksimalkan perencanaan pajaknya dalam menentukan besarnya pajak yang harus dibayar. Hal tersebut dapat dibuktikan dari besarnya pajak penghasilan perusahaan ini yang selalu bergerak di sekitar angka USD 160.000 ke atas atau sekitar Rp 2 Miliar dalam dua tahun dan meningkatnya persentase perbandingan antara pajak penghasilan dan pendapatan dari tahun 2017 ke tahun 2018. Tidak hanya untuk meminimalkan beban pajak, perencanaan pajak ini juga sekaligus diterapkan untuk meningkatkan kinerja perusahaan. Oleh karena itu, penulis membuat penelitian dengan judul "Analisis Perencanaan Pajak Sebagai Upaya Meminimalkan Beban Pajak dan Meningkatkan Kinerja Perusahaan pada PT XYZ”.

\section{Permasalahan}

Berikut ini adalah data pajak penghasilan PT XYZ selama 2 tahun terakhir.

Tabel 1 Data Pajak Penghasilan PT $X Y Z$

\begin{tabular}{|l|l|l|l|l|}
\hline No. & Tahun & Pendapatan & $\begin{array}{c}\text { Pajak } \\
\text { Penghasilan }\end{array}$ & Persentase \\
\hline 1 & 2017 & $\begin{array}{l}\text { USD2.395.5 } \\
66\end{array}$ & $\begin{array}{l}\text { USD } \\
184.624\end{array}$ & $7,71 \%$ \\
\hline 2 & 2018 & $\begin{array}{l}\text { USD } \\
2.061 .490\end{array}$ & $\begin{array}{l}\text { USD } \\
178.018\end{array}$ & $8,64 \%$ \\
\hline
\end{tabular}

Sumber: Data PT XYZ

Dapat dilihat dari data di atas bahwa persentase perbandingan pajak penghasilan dan pendapatan PT XYZ mengalami kenaikan dari tahun 2017 ke tahun 2018. Maka dari itu, PT XYZ membutuhkan perencanaan pajak yang lebih baik untuk meminimalkan beban pajaknya. Selain itu, dengan adanya perencanaan pajak ini diharapkan kinerja perusahaan PT XYZ dapat meningkat.

\section{Tujuan}

Berdasarkan pertanyaan penelitian diatas, tujuan dilakukannya penelitian ini adalah:

1. mendeskripsikan pemenuhan kewajiban perpajakan PT XYZ selama ini, 
2. menganalisis perencanaan pajak yang dapat diterapkan PT XYZ, dan

3. menganalisis kinerja perusahaan PT XYZ setelah perencanaan pajak diterapkan.

\section{TINJAUAN PUSTAKA Pengertian Pajak}

Pajak adalah iuran rakyat kepada kas negara berdasarkan undang-undang (yang dapat dipaksakan) dengan tidak mendapat jasa timbal balik (kontraprestasi) yang langsung dapat ditunjukkan dan yang digunakan untuk membayar pengeluaran umum (Soemitro dalam Resmi, 2016).

\section{Pajak Penghasilan Badan}

Pengertian Pajak Penghasilan Badan

Pajak Penghasilan (PPh) Badan merupakan pajak yang dikenakan atas penghasilan yang diterima atau diperoleh oleh badan dalam suatu Tahun Pajak (Wardoyo, Subiyakto, \& Argo, 2015).

\section{Rekonsiliasi Fiskal}

Wajib Pajak melakukan rekonsiliasi fiskal karena adanya perbedaan perhitungan antara laba menurut akuntansi (komersial) dan laba menurut perpajakan (fiskal) (Resmi, 2016). Selanjutnya, Resmi juga memaparkan perbedaan apa saja yang dapat terjadi.

1. Perbedaan prinsip akuntansi seperti prinsip konservatisme, prinsip harga perolehan (cost), dan prinsip pemadanan (matching) biaya-manfaat.

2. Perbedaan metode dan prosedur akuntansi seperti metode penilaian persediaan, metode penyusutan dan amortisasi, dan metode penghapusan piutang.

3. Perbedaan perlakuan dan pengakuan penghasilan dan biaya seperti penghasilan yang tidak termasuk objek pajak penghasilan, penghasilan yang termasuk objek pajak penghasilan final, kerugian usaha di luar negeri, dan pengeluaran tertentu yang tidak diakui dalam fiskal.

\section{Perencanaan Pajak}

\section{Pengertian Perencanaan Pajak}

Perencanaan pajak adalah proses mengelola usaha wajib pajak atau kelompok usaha wajib pajak sehingga utang pajaknya berada dititik paling minimal berdasarkan ketentuan perundang-undangan perpajakan maupun secara komersial (Faisal, 2009). Jika ada pilihan-pilihan yang tersedia dalam melaksanakan kewajiban perpajakan seperti metode, fasilitas, dan ketentuan peraturan lainnya yang dapat memperkecil pembayaran pajak maka pilihlah yang dapat menghasilkan beban pajak terkecil(Tampubolon, 2018).

\section{Tujuan dan Manfaat Perencanaan Pajak}

Tujuan dilakukannya perencanaan pajak ini diantaranya adalah untuk meminimalisasi beban pajak yang terutang, memaksimalkan laba setelah pajak, meminimalkan terjadinya kejutan pajak (tax surprise) jika terjadi pemeriksaan pajak oleh fiskus, memenuhi kewajiban perpajakan secara benar, efektif, dan efisien (Pohan, 2013). Dari tujuan tersebut, Pohan juga memaparkan bahwa manfaat perencanaan pajak adalah penghematan kas keluar, mengatur cash flow karena perusahaan dapat mengatur anggaran kas dengan lebih akurat.

\section{Tahapan Perencanaan Pajak}

Menurut Spitz dalam Pohan (2013), ada lima urutan tahap-tahap yang dapat dilakukan untuk melakukan perencanaan pajak.

1. Menganalisis informasi yang ada

2. Buat satu model atau lebih rencana besarnya pajak

3. Evaluasi atas perencanaan pajak

4. Mencari kelemahan dan kemudian memperbaiki kembali rencana pajak

5. Mutakhirkan rencana pajak

\section{Kinerja Perusahaan \\ Pengertian Kinerja Perusahaan}

Kinerja perusahaan adalah sebuah hasil kerja yang diperoleh dari tercapainya tujuan strategis perusahaan, kepuasan pelanggan, dan kontribusi ekonomi (Awantara, 2013). Menurut Moerdiyanto dalam Saefi, Kesuma, dan Lahaya (2017), kinerja perusahaan merupakan hasil dari serangkaian proses bisnis dengan mengorbankan berbagai sumber daya, baik sumber daya manusia maupun keuangan perusahaan.

\section{Pengukuran Kinerja Perusahaan}

Menurut Kuncoro, Tandelilin, \& Ancok (2009), analisis rasio keuangan merupakan pendekatan yang umum digunakan sebagai alat pengukur kinerja perusahaan.

Termasuk rasio keuangan diantaranya adalah rasio likuiditas dan rasio solvabilitas. Rasio likuiditas (liquidity ratio)adalah rasio yang menggambarkan kemampuan perusahaan dalam memenuhi kewajiban 
jangka pendeknya, sedangkan rasio solvabilitas digunakan untuk mengukur kemampuan perusahaan dalam membayar seluruh kewajibannya apabila perusahaan tersebut dilikuidasi atau dibubarkan. (Kasmir, 2009). Selanjutnya menurut Zulfikar (2016) untuk rasio likuiditas dapat dihitung menggunakan rasio lancar dengan rumus aset lancar dibagi kewajiban lancar dan rasio kas dengan rumus kas dibagi kewajiban lancar, sedangkan untuk rasio solvabilitas dapat dihitung menggunakan rasio hutang terhadap aset (debt to asset ratio) dengan rumus utang dibagi asset.

\section{METODE PENELITIAN}

Dalam penelitian ini, penulis melakukan penelitian kualitatif dengan hasil berupa rekomendasi perencanaan pajak.

Objek dari penelitian ini adalah Pajak Penghasilan Badan PT XYZ (disamarkan atas permintaan perusahaan) tahun 2018 yang dapat meminimalkan beban pajak dan sekaligus meningkatkan kinerja perusahaan serta beban-beban dalam Laporan Laba Rugi PT XYZ tahun 2018 khususnya yang mengalami koreksi fiskal.

Teknik pengambilan sampel Purposive Non-probability Sampling yang didapat dari Staff Divisi Accounting PT XYZ.

Berikut ini adalah jenis data yang digunakan dalam penelitian:

1. Data kuantitatif adalah data beban atau biaya PT XYZ selama tahun 2018 dan Pajak Penghasilan Badan PT XYZ tahun 2018, laporan rekonsiliasi fiskal PT XYZ tahun 2018. Data ini didapat langsung dari perusahaan.

2. Data kualitatif berupa informasi umum tentang PT XYZ yang didapat dengan wawancara langsung serta melakukan pengamantan di PT XYZ.

Penulis melakukan observasi dengan mengamati hal-hal seperti cara perusahaan dalam mengambil keputusan terutama keputusan yang berkaitan dengan perpajakan serta cara pembuatan laporan keuangan dan laporan rekonsiliasi fiskal perusahaan.Selain itu, penulis juga akan melakukan kajian terhadap beberapa literasi dan penelitian terdahulu yang berkaitan dengan topik dari penelitian ini.

Menurut Miles dan Huberman (dalam Sekaran, 2017) terdapat tiga langkah dalam melakukan analisis data kualitatif
1. Reduksi data dilakukan dengan memilih beban-beban dari Laporan Laba Rugi PT XYZ di tahun 2018 yang telah dikoreksi menurut fiskal.

2. Penyajian data atau data displaydilakukan dengan menjelaskan alasan beban-beban tersebut mengalami koreksi fiskal beserta nominal yang dikoreksi.

3. Penarikan kesimpulan dilakukan dengan menjelaskan hasil analisis yang dilakukan penulis mengenai langkah-langkah yang dapat diambil oleh PT XYZ untuk merencanakan pajaknya sehingga beban pajaknya dapat berkurang dan kinerja perusahaannya dapat meningkat.

\section{HASIL DAN PEMBAHASAN \\ Pemenuhan Kewajiban Perpajakan PT XYZ}

Sebagai Wajib Pajak Badan di Indonesia, tentunya PT XYZ telah melaksanakan kewajiban perpajakan sesuai ketentuan yang berlaku.

1. Kewajiban Pendaftaran NPWP (Nomor Pokok Wajib Pajak)

PT XYZ telah telah mendaftarkan usahanya di kantor Direktorat Jenderal Pajak sebagai Wajib Pajak Badan sekaligus Pengusaha Kena Pajak (PKP). Oleh karena itu, PT XYZ sudah memiliki NPWP sebagai sarana dalam administrasi perpajakan yang digunakan sebagai tanda pengenal diri atau identitas Wajib Pajak dalam melaksanakan hak dan kewajiban perpajakannya menurut Pasal 1 angka 6 UU KUP. Berdasarkan UU KUP Pasal 2 Ayat 1, PT XYZ harus melaksanakan kewajiban pendaftaran NPWP serta pengukuhan PKP di KPP (Kantor Pelayanan Pajak) tempat keududukan PT XYZ yaitu Kota Jakarta.

Selain itu, PT XYZ juga sudah meminta izin kepada Menteri Keuangan untuk menyusun laporan keuangan dalam Bahasa Inggris dan mata uang asing Dolar Amerika Serikat.

2. Kewajiban PPh Terutang Badan

a. Perhitungan PPh Terutang

Berikut ini adalah laporan laba rugi PT XYZ beserta koreksi fiskalnya. 


\section{Gambar 1 Laporan Rekonsiliasi Fiskal PT XYZ PT XYZ \\ STATEMENT OF PROFIT OR LOSS AND FISCAL CORRECTION FOR THE YEAR ENDED 31 DECEMBER 2018 (EXPRESSED IN USD)}

\begin{tabular}{|c|c|c|c|c|}
\hline & \multirow{2}{*}{ Commercial } & \multicolumn{2}{|c|}{ Fiscal Correction } & \multirow{2}{*}{ Fiscal } \\
\hline & & Temporary & Permanent & \\
\hline Revenue & 2.061 .490 & & & 2.061 .490 \\
\hline Cost of Revenue & $(221.327)$ & & & $(221.327)$ \\
\hline Gross Profit & 1.840 .163 & - & - & 1.840 .163 \\
\hline \multicolumn{5}{|l|}{ Operating Expense } \\
\hline Personnel & 645.682 & (28.531) & $(139.862)$ & 477.289 \\
\hline License and service fee & 485.800 & & & 485.800 \\
\hline Facilities, rent and maintenance & 74.903 & & & 74.903 \\
\hline Travel and entertainment & 62.012 & & $(22.250)$ & 39.762 \\
\hline Professional fees & 29.055 & & $(2.500)$ & 26.555 \\
\hline Depreciation & 27.879 & & (5.184) & 22.695 \\
\hline Office supplies & 22.179 & & $(3.955)$ & 18.224 \\
\hline Others - Net & 71.799 & (8.781) & $(33.291)$ & 29.727 \\
\hline Total Operating Expense & 1.419 .309 & (37.312) & (207.042) & 1.174 .955 \\
\hline Profit From Operation & 420.854 & 37.312 & 207.042 & 665.208 \\
\hline \multicolumn{5}{|l|}{ Other Charges (Income) } \\
\hline Financial Income & $(14.051)$ & & 5.148 & $(8.903)$ \\
\hline Financial Expense & 18.522 & & & 18.522 \\
\hline Others-Net & $(117.962)$ & & (683) & $(118.645)$ \\
\hline Total Other Charges (Income) & (113.491) & - & 4.465 & $(109.026)$ \\
\hline Income Before Income Tax Benefit (Expense) & 534.345 & 37.312 & 202.577 & 774.234 \\
\hline
\end{tabular}

Sumber: Data PT XYZ

Dapat dilihat dari gambar tersebut bahwa ada banyak beban yang mendapat koreksi fiskal selama tahun 2018. Berikut ini adalah penjelasan dari masing-masing koreksi tersebut.

1. Personnel

Beban personnel memperoleh koreksi positif sebesar USD 168.393 yang terbagi atas USD 28.531 sebagai koreksi temporer dan sisanya sebesar USD 139.862 sebagai koreksi permanen. Nilai sebesar USD 28.531 yang merupakan koreksi fiskal temporer positif adalah koreksi dari gratuity yang merupakan imbalan pasca kerja yang pembayarannya masih berupa beban akrual atau dicadangkansehingga tidak termasuk deductible expense. Sisanya yang sebesar USD 139.862 dikoreksi karena hal-hal berikut ini.

a. Sebagian dari annual wages or bonus sebesar USD 10.852 dibayarkan melalui natura.

b. Pension adalah iuran pensiun sebesar USD 20.160 dibayarkan kepada Dana Pensiun yang belum disahkan Menteri Keuangan.

c. Housing rent, electricity, and others expense adalah beban sewa rumah, beban listrik rumah dan beban rumah lainnya sebesar USD 52.751 yang digunakan untuk penyewaan rumah bagi karyawan.

d. Insurance atau premi asuransi sebesar USD 39.860 yang dibayar oleh karyawan. e. Leave travel adalah biaya perjalanan yang dilakukan oleh karyawan sebesar USD 16.239 tidak didukung dengan bukti-bukti yang cukup. PT XYZ memberlakukan metode lumpsum tanpa bukti pengeluaran untuk metode pembayaran perjalanan dinas karyawan. Dalam hal ini, PT XYZ tidak meminta bukti-bukti atas pengeluaran yang dikeluarkan oleh karyawan selama perjalanan sehingga biaya perjalanan ini harus dikoreksi menurut fiskal.

2. Travel and Entertainment

Beban ini dikoreksi fiskal negatif sebesar USD 22.250. Berikut ini adalah beban yang termasuk dalam travel and entertainment yang dikoreksi menurut fiskal.

a. Entertainment adalah beban yang dikeluarkan oleh PT XYZ untuk menjamu tamu-tamunya. Beban sebesar USD 15.842 ini dikoreksi karena tidak menggunakan daftar nominatif.

b. Visa \& migration dikoreksi sebesar USD 158 karena biaya ini adalah biaya yang digunakan untuk membiayai direktur dalam proses imigrasinya ke Indonesia.

c. Other marketing dikoreksi sebesar USD 6.250 karena tidak disertai dengan daftar nominatif.

3. Professional fees merupakan beban yang dikeluarkan untuk membayar tenaga ahli. Sebesar USD 2.500 dari beban ini dikoreksi fiskal positif karena pembayarannya diberikan dalam bentuk natura.

4. Depreciation memperoleh koreksi fiskal positif sebesar USD 5.184 karena ini adalah beban depresiasi untuk kendaraan direktur.

5. Office Supplies

Beban yang dikoreksi dalam kategori ini terdiri dari sebagai berikut.

a. Fuel adalah pengeluaran untuk pembelian bensin. Biaya sebesar USD 3.429 yang dikeluarkan untuk membeli bensin ini dikoreksi setengahnya karena kendaraannya digunakan oleh direktur sehingga hanya diakui sebesar USD 1.715 .

b. Parking adalah pengeluaran untuk pembayaran parkir. Biaya parkir ini juga merupakan biaya yang hanya dapat diakui setengahnya karena merupakan biaya parkir untuk kendaraan direktur. Biaya menurut komersil berjumlah USD 2.244 
dan harus dikoreksi positif sebesar USD 1.122 .

c. Service adalah pengeluaran yang digunakan untuk servis kendaraan. Kendaraan yang diservis dalam biaya ini adalah kendaraan yang diperuntukan kepada direktur sehingga biaya untuk servis kendaraan sebesar USD 674 hanya dapat diakui setengahnya yaitu sebesar USD 337.

d. Beverages adalah biaya yang digunakan untuk menyediakan minuman sebesar USD 781. Beban tersebut dikoreksi fiskal positif oleh perusahaan karena bukan disediakan untuk karyawan melainkan untuk tamu.

6. Other Operating Expense - Net

Berikut penjelasan koreksi fiskal dalam beban ini.

a. Mobile phone merupakan biaya pembelian pulsa yang digunakan untuk menunjang pekerjaan karyawan sebesar USD 7.784. Beban tersebut harus dikoreksi setengahnya yaitu sebesar USD 3.892 .

b. Meeting expenses adalah beban yang dikeluarkan untuk jamuan dalam rapat. Sebesar USD 1.888 dari beban ini dikoreksi fiskal positif karena tidak melampirkan daftar nominatif saat pelaporannya.

c. Research and development adalah beban yang dikeluarkan dalam hal penelitian dan pengembangan. Sebesar USD 15.418 dari beban ini mendapatkan koreksi fiskal positif karena bukan dilakukan di Indonesia melainkan di luar negeri.

d. Staff or company event adalah beban yang digunakan untuk acara yang dibuat untuk karyawan seperti family gathering. Maka dari itu, sebesar USD 7.558 mengalami koreksi fiskal karena termasuk dalam pemberian imbalan dalam bentuk natura.

e. Corporate Social Resonsibility (CSR)/Donation sebesar USD 4.535 dikoreksi secara fiskal karena beban tersebut dikeluarkan untuk donasi kepada karyawan dan kegiatan CSR yang dilakukan oleh PT XYZ. Di tahun 2018, PT XYZ memberikan donasi tersebut kepada karyawannya sejumlah USD 720. Untuk kegiatan CSR, PT XYZ menyalurkan donasi sebesar USD 3.815 di bidang pendidikan yang berkaitan dengan pendidikan pencegahan HIV dan AIDS. Donasi tersebut dikoreksi secara fiskal karena PT XYZ bukan memberikan fasilitas pendidikan.

f. Bad \& doubtful debt adalah beban kerugian piutang yang diakui berdasarkan metode cadangan sehingga beban ini dikoreksi menurut fiskal sebesar USD 8.781.

7. Financial income yang mendapat koreksi fiskal adalah interest income atau pendapatan bunga karena pendapatan bunga sudah dikenakan pajak final berdasarkan PPh Final 4 (2). Pendapatan bunga ini dikoreksi fiskal negatif sebesar USD 5.148.

8. Others - Net

Exchange rate differencies atau rugi selisih kurs senilai USD 683 dikenakan koreksi fiskal positif karena merupakan rugi selisih kurs dari transaksi penghasilan final yang diatur dalam Pasal 4 (2) UU No. 36 Tahun 2008.

Setelah laba fiskal atau PKP sudah ditentukan jumlahnya, maka nilai tersebut dapat langsung dikalikan dengan tarif pajak yang berlaku. PT XYZ mengenakan tarif pajak seusai pasal 31E UU No. 36 Tahun 2008. Langkah awal yang dilakukan PT XYZ dalam menerapkan tarif ini adalah dengan menghitung besarnya PKP yang menerima fasilitas dan yang tidak menerima fasilitas. Jika dihitung dengan kurs Rp 14.500/\$, maka nilai $\mathrm{Rp}$ 4.800.000.000 senilai dengan USD $331.034,48$.

PKP Fasilitas:

$$
\begin{aligned}
& \frac{331.034,48}{2.061 .490} \times 774.234=124.327 \\
& \text { PKP Non-Fasilitas: } \\
& 774.234-124.327=649.907
\end{aligned}
$$

Setelah itu, barulah masing-masing PKP dikalikan dengan tarif pajaknya masingmasing.

Pajak Penghasilan Fasilitas:

$50 \% \times 25 \% \times 124.327=15.541$

Pajak Penghasilan Non-Fasilitas:

$$
25 \% \times 649.907=162.477
$$

Beban Pajak Terutang:

$$
15.541+162.477=178.018
$$

Maka, pajak terutang PT XYZ tahun 2018 adalah sebesar USD 178.018.

Setelah diketahui pajak terutang PT XYZ di tahun 2018, selanjutnya PT XYZ harus menentukan PPh Kurang/Lebih Bayarnya. Berikut ini adalah perhitungannya. 


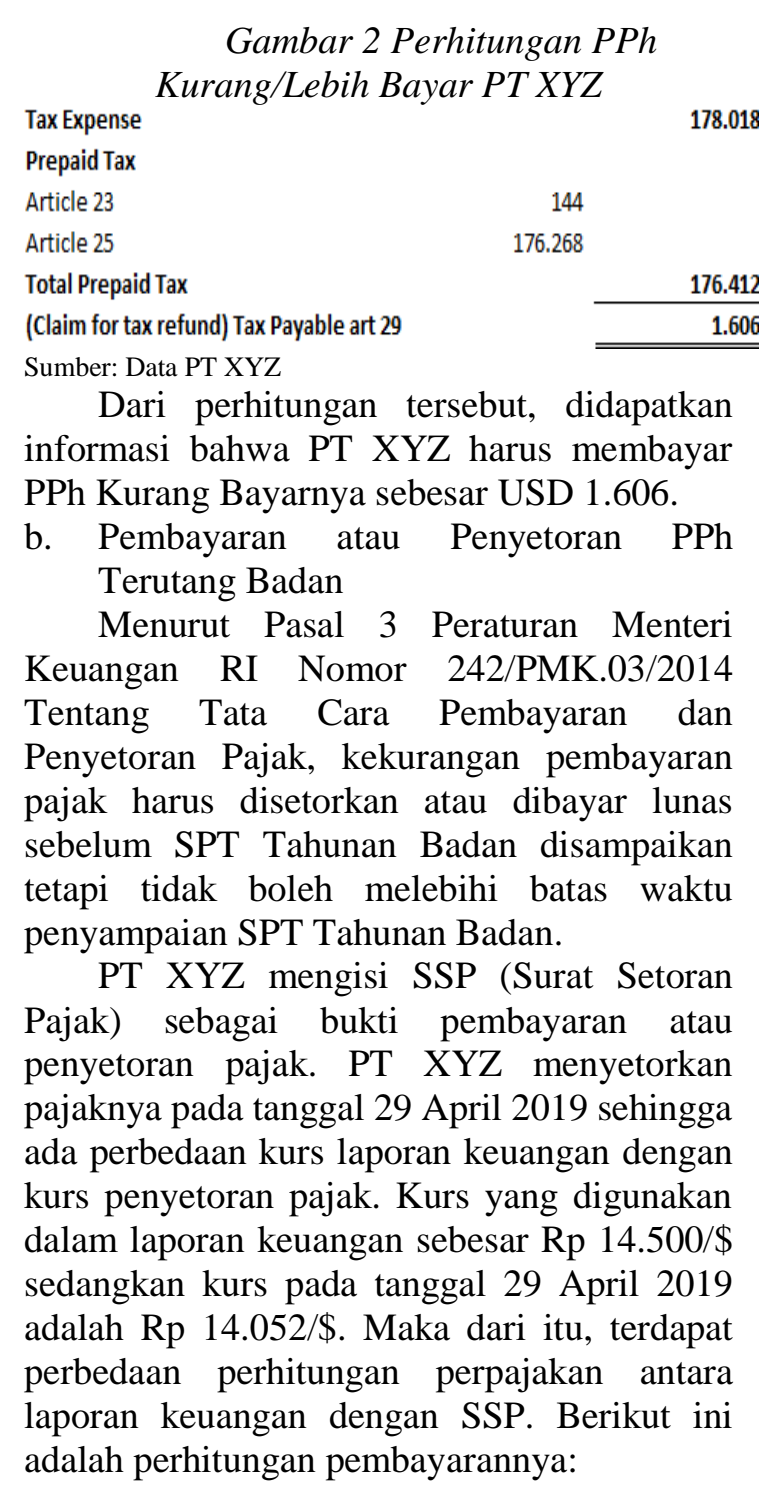
PPh Pasal $29 \times$ Kurs KMK 29 April 2019$$
=1.606 \times 14.052
$$$$
=22.567 .512
$$

Dengan demikian, PT XYZ harus membayar pajak kurang bayarnya sebesar Rp 22.567.512.

\section{c. Pelaporan PPh Terutang Badan}

PT XYZ melaporkan $\mathrm{PPh}$ terutang badannya di tanggal yang sama dengan penyetoran tahunan $\mathrm{PPh}$ badan yaitu tanggal 29 April 2019. Maka dari itu, PT XYZ tidak dikenakan denda keterlambatan penyampaian SPT karena batasnya adalah tanggal 30 April 2019. PT XYZ menggunakan SPT Tahunan Wajib Pajak Badan formulir 1771-\$.

\section{Analisis Perencanaan Pajak}

Setelah menganalisa laporan rekonsiliasi fiskal PT XYZ, berikut ini strategi perencanaan pajak yang dapat penulis sampaikan.

\section{Membuat Daftar Nominatif}

PT XYZ dapat membuat daftar nominatif untuk beban entertainment, other marketing, dan meeting expenses. Selain itu, beban beverages sebaiknya dimasukkan ke dalam akun beban entertainment dan dibuat daftar nominatifnya.

Jika PT XYZ melakukan pembuatan daftar nominatif tersebut dan melampirkannya saat melakukan pelaporan pajak, maka beban fiskal PT XYZ dapat bertambah sebesar USD 19.761 .

2. Membayarkan Premi Asuransi Karyawan dan Menjadikannya sebagai Penghasilan bagi Karyawan

PT XYZ dapat membayarkan premi asuransi karyawan dan menjadikannya sebagai penghasilan bagi karyawannya. Jika PT XYZ melakukan hal demikian, maka PT XYZ dapat menambah beban fiskal sebesar USD 39.860.

3. Pengalihan Pemberian Imbalan dalam Bentuk Natura Menjadi Pemberian dalam Bentuk Uang

Penulis memberikan alternatif kepada PT XYZ untuk memberikan imbalan bonus tahunan atau annual wages or bonus dan professional fees dalam bentuk uang atau tunjangan. Alternatif ini tidak mengubah nilai dari pemberian imbalan tersebut melainkan hanya mengubah bentuk pemberiannya saja. Jika PT XYZ memberikan imbalan tersebut dalam bentuk uang tentunya akan mengurangi PKP PT XYZ sebesar USD 13.352 dan mengurangi nilai beban pajaknya juga.

4. Membayar Iuran Pensiun Kepada Dana Pensiun yang Telah Disahkan Oleh Menteri Keuangan

Jika perusahaan membayar iuran pensiunnya kepada Dana Pensiun yang telah disahkan Menteri Keuangan maka nominal sebesar USD 20.160 tidak perlu dikoreksi.

5. Mengganti Metode Pembiayaan Perjalanan Dinas Karyawan

Jika PT XYZ mengharuskan karyawan memberikan bukti-bukti pengeluarannya kepada PT XYZ maka biaya tersebut dapat diakui menurut fiskal. Akibatnya, PT XYZ dapat menambah deductible expense sebesar USD 16.239.

6. Melakukan Penelitian dan Pengembangan di Indonesia

Disarankan supaya PT XYZ melakukan penelitiannya di Indonesia supaya biaya penelitian sebesar USD 15.418 tidak dikoreksi secara fiskal. 
7. Melakukan Kegiatan Corporate Social Resposibility (CSR) Menurut UU No. 36 Tahun 2008

Jika PT XYZ melakukan kegiatan CSR dibidang-bidang yang disebutkan dalam UU No. 36 Tahun 2008 tersebut dan sesuai dengan PP terkait maka PT XYZ dapat mengakui beban CSR-nya sebesar USD 3.815 secara fiskal.

Perbandingan laporan laba rugi sebelum dan setelah perencanaan pajak jika PT XYZ menerapkan perencanaan pajak berdasarkan rekomendasi penulis ditunjukan dalam Gambar 3.

Jika PT XYZ menerapkan perencanaan pajak tersebut maka laba fiskal PT XYZ akan menurun menjadi USD 640.629. Berikut ini adalah perhitungan beban pajak PT XYZ setelah perencanaan pajak.

PKP Fasilitas:

$$
\begin{aligned}
& \frac{331.034,48}{2.061 .490} \times 640.629=102.872 \\
& \text { PKP Non-Fasilitas: } \\
& 640.629-102.872=537.757 \\
& \text { Pajak Penghasilan Fasilitas: } \\
& 50 \% \times 25 \% \times 102.872=12.859 \\
& \text { Pajak Penghasilan Non-Fasilitas: } \\
& 25 \% \times 537.757=134.439 \\
& \text { Beban Pajak: } \\
& 12.859+134.439=147.298
\end{aligned}
$$

Maka setelah perencanaan pajak, beban pajak yang harus dibayar PT XYZ adalah sebesar USD 147.298. Jika beban pajak sebelum perencanaan pajak adalah USD 178.018 maka rekomendasi pajak ini berhasil mengurangi beban pajak sebesar USD 30.720 .

Gambar 3 Perbandingan Laporan

Laba Rugi Fiskal PT XYZ

PT XYZ

PERBANDINGAN LAPORAN LABA RUGI FISKAL SEBELUUM DAN SESUDAH PERENCANAAN PAJAK (DINYATAKAN DALAM SATUAN USD)

\begin{tabular}{rrr}
\multicolumn{1}{l}{$\begin{array}{c}\text { Sebelum } \\
\text { Perencanaan Pajak }\end{array}$} & Perbedaan & \multicolumn{1}{c}{$\begin{array}{c}\text { Setelah } \\
\text { Perencanaan Pajak }\end{array}$} \\
\hline 2.061 .490 & & 2.061 .490 \\
$(221.327)$ & & $(221.327)$ \\
\hline 1.840 .163 & - & 1.840 .163 \\
& & \\
4777.289 & 87.111 & 564.400 \\
485.800 & & 485.800 \\
74.903 & & 74.903 \\
39.762 & 22.092 & 61.854 \\
26.555 & 2.500 & 29.055 \\
22.695 & & 22.695 \\
18.224 & 781 & 19.005 \\
29.727 & 21.121 & 50.848 \\
\hline 1.174 .955 & 133.605 & 1.308 .560 \\
\hline 665.208 & $(133.605)$ & 531.603 \\
& & \\
$(8.903)$ & & $(8.903)$ \\
18.522 & & 18.522 \\
$(118.645)$ & & $(118.645)$ \\
\hline$(109.026)$ & - & $(109.026)$ \\
\hline 774.234 & $(133.605)$ & 640.629 \\
\hline & & \\
\hline & & \\
\hline & & \\
\hline
\end{tabular}

Income Before Income Tax Benefit (Expense)

Sumber: Data Diolah

Selanjutnya, berikut ini adalah perhitungan PPh Kurang/Lebih Bayar PT XYZ jika perencanaan pajak tersebut diterapkan.

Gambar 4 PPh Kurang/Lebih Bayar

PT XYZ Setelah Perencanaan Pajak

Tax Expense

Prepaid Tax

Article 23

Article 25

Total Prepaid Tax

(Claim for tax refund art 28) Tax Payable art 29

Sumber : Data Diolah

Dari perhitungan tersebut, diketahui bahwa PT XYZ mengalami lebih bayar pajak (PPh Pasal 28) sebesar USD 29.114 jika menerapkan perencanaan pajak berdasarkan rekomendasi penulis.

\section{Analisis Pengukuran Kinerja Perusahaan}

Perbandingan perhitungan $\mathrm{PPh}$ Kurang/Lebih Bayar antara sebelum dan sesudah perencanaan pajak jika PT XYZ menerapkan perencanaan pajak ditunjukan dalam Gambar 5.

Dari gambar tersebut, dapat dilihat bahwa sebelum perencanaan pajak terdapat $\mathrm{PPh}$ Kurang Bayar sebesar USD 1.606 yang menjadi nilai utang pajak PPh 29. Kemudian setelah perencanaan pajak diterapkan, $\mathrm{PPh}$ Kurang Bayar tersebut berubah menjadi PPh Lebih Bayar Pasal 28. Hal inilah yang mendasari perubahan nilai pada akun-akun di laporan posisi keuangan. Akun utang pajak PPh 29 akan menjadi USD 0 sedangkan nilai 
PPh Lebih Bayar sebesar USD 29.114 akan masuk kedalam akun piutang sebagai klaim atas pengembalian pajak yang tergolong dalam aset lancar dan akan diajukan sebagai restitusi. Gambar 5 Perbandingan PPh Kurang/Lebih Bayar

\begin{tabular}{|c|c|c|c|}
\hline & 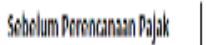 & 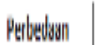 & Stotih Pron \\
\hline Tablews: & INaw & $|z| \pi|n|$ & $1 / 2$ \\
\hline Prtpadid lax & & & \\
\hline Attl:an & 进 & & I.4 \\
\hline Attlo: as & mathas & & bias \\
\hline That Praphil The & 17ikith & & $177 \mathrm{a}$ \\
\hline 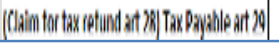 & 1.6inif & anm & \$.1.1. \\
\hline
\end{tabular}

Setelah itu barulah kinerja perusahaan setelah perencanaan pajak dapat dihitung. Berikut ini adalah analisis pengukuran kinerja perusahaan pada PT XYZ berdasarkan beberapa rasio keuangan.

1. Analisis Likuiditas

a. Rasio Lancar (Current Ratio)

Berikut ini adalah perhitungan rasio lancar PT XYZ tahun 2018.

$$
\begin{aligned}
\text { Aset Lancar } & =\frac{8.783 .779}{8.187 .729} \\
& =107,28 \%
\end{aligned}
$$

Adanya penurunan nilai utang dan kenaikan nilai piutang sebagai akibat dari perencanaan pajak, maka rasio lancar PT XYZ meingkat menjadi 107,66\%. Kenaikan tersebut berarti bahwa kemampuan PT XYZ dalam membayar hutang-hutangnya dapat meningkat sebesar $0,38 \%$.

b. Rasio Kas (Cash Ratio)

Berikut ini adalah perhitungan rasio kas tahun 2018 sebelum perencanaan pajak.

$$
\begin{aligned}
\frac{\text { Kas dan Setara Kas }}{\text { Liabilitas Lancar }} & =\frac{2.522 .291}{8.187 .729} \\
& =30,805 \%
\end{aligned}
$$

Adanya penurunan nilai liabilitas lancar mengakibatkan rasio kas PT XYZ meningkat menjadi $30,811 \%$. Kenaikan rasio ini dapat menggambarkan bahwa kemampuan PT XYZ dalam menutup hutang-hutangnya dengan kas dan setara kas dapat meningkat sebesar $0,006 \%$.

2. Analisis Solvabilitas

a. Rasio Hutang (Debt Ratio)

Berikut ini adalah perhitungan rasio hutang PT XYZ tahun 2018 sebelum perencanaan pajak.

$$
\begin{aligned}
\frac{\text { Total Liabilitas }}{\text { Total Aset }} & =\frac{8.444 .137}{8.970 .604} \\
& =94,13 \%
\end{aligned}
$$

Kenaikan piutang dan penurunan utang menjadi penyebab menurunnya rasio hutang PT XYZ menjadi 93,81\%. Penurunan ini berarti bahwa PT XYZ dapat mengurangi risiko finansialnya yang dinilai menurut rasio solvabilitas sebesar $0,32 \%$.

\section{PENUTUP \\ Kesimpulan}

Berdasarkan pemaparan dari hasil penelitian dan pembahasan dapat diambil kesimpulan sebagai berikut.

1. PT XYZ sudah melakukan pendaftaran NPWP (Nomor Pokok Wajib Pajak) di salah satu KPP (Kantor Pelayanan Pajak) di Kota Jakarta. Dari perhitungan PPh Terutang diperoleh bahwa PT XYZ memiliki PPh Terutang sebesar USD 178.018 dan PPh Kurang Bayar sebesar USD 1.606 di tahun 2018. PT XYZ kemudian menyetor dan melaporkan pajaknya di tanggal yang sama yaitu 29 April 2019. Besarnya pajak yang dibayar oleh PT XYZ adalah Rp 22.567.512. Dalam melaporkan pajaknya, PT XYZ menggunakan SPT 1771-\$.

2. Jika PT XYZ menerapkan perencanaan pajak ini maka PT XYZ dapat mengurangi beban pajak sebesar USD 30.720 sehingga beban pajak PT XYZ menjadi USD 147.298. Dampak dari penurunan beban pajak ini adalah PPh Kurang Bayar PT XYZ yang semula sebesar USD 1.606 berubah menjadi PPh Lebih Bayar sebesar USD 29.114.

3. Berdasarkan rasio lancar (Current Ratio), PT XYZ dapat meningkatkan kemampuannya dalam menutup hutanghutangnya menggunakan aset lancar sebesar 0,38\%. Kemudian berdasarkan rasio kas (Cash Ratio), PT XYZ dapat meningkatkan kemampuannya dalam melunasi hutang-hutangnya menggunakan kas sebesar 0,006\%. Terakhir, PT XYZ dapat meningkatkan kemampuannya dalam menghindari risiko finansialnya sebesar $0,32 \%$ berdasarkan rasio hutang (Debt Ratio).

\section{Saran}

Saran untuk PT XYZ terkait perencanaan pajak adalah menerapkan rekomendasi perencanaan pajak yang telah disampaikan 
oleh penulis seperti membuat daftar nominatif, mambayarkan premi asuransi karyawan, mengalihkan pemberian natura menjadi pemberian dalam bentuk uang atau tunjangan, membayarkan pensiun kepada Dana Pensiun yang telah disahkan oleh Menteri Keuangan, meminta bukti-bukti atas perjalanan dinas karyawan, melakukan peneltian dan pengembangan di Indonesia, dan melakukan kegiatan CSR (Corporate Social Responsibility) sesuai UU No. 36 Tahun 2008. Selain itu, PT XYZ sebaiknya memasukan beban pembelian minuman ke dalam akun beban entertainment supaya dapat dibuat daftar nominatifnya sehingga tidak dikenakan koreksi fiskal positif.

\section{DAFTAR PUSTAKA}

Awantara, I. G. (2013). Sistem Manajemen Lingkungan Perspektif Agrokompleks. Yogyakarta: Deepublish.

Faisal, G. S. (2009). How To Be A Smarter Taxpayer. Jakarta: Grasindo.

Hery. (2015). Analisis Kinerja Manajemen. Jakarta: Grasindo.

Hien, K. S., \& Mariani, F. I. (2017). Financial Management Canvas. Jakarta: Gramedia.

Kasmir. (2009). Pengantar Manajemen Keuangan. Jakarta: Kencana.

Kuncoro, M., Tandelilin, E., \& Ancok, D. (2009). Transformasi Pertamina: Dilema Antara Orientasi Bisnis \&Pelayanan Publik. Yogyakarta: Galangpress.

Lubis, I. (2009). Memudahkan Urusan Pajak Bagi Perorangan, Suami-Istri, Usaha, dan Yayasan. Jakarta: Kompas Gramedia.

Muljono, D. (2009). Tax Planning-Menyiasati Pajak dengan Bijak. Yogyakarta: CV. ANDI OFFSET.

Nofriansyah, D., \& Nurcahyo, G. W. (2019). Algoritma Data Mining Dan Pengujian. Yogyakarta: Deepublish.

Pemerintah Indonesia. (2008). UndangUndang Nomor 36 Tahun 2008 Tentang Perubahan Keempat Atas Undang-Undang Nomor 7 Tahun 1983 Tentang Pajak Penghasilan. Jakarta: Sekretariat Negara.

Pohan, C. A. (2013). Manajemen Perpajakan Strategi Perencanaan Pajak dan Bisnis Edisi Revisi. Jakarta: PT Gramedia Pustaka Utama.
Resmi, S. (2016). Perpajakan: Teori dan Kasus. Jakarta: Salemba Empat.

Saefi, F. R., Kesuma, A. I., \& Lahaya, I. A. (2017). Implementasi Tax Planning dalam Upaya Peningkatan Kinerja Perusahaan. KINERJA, 70-79.

Sekaran, U., \& Bougie, R. (2017). Metode Penelitian untuk Bisnis (6 ed., Vol. 1). (K. M. Yon, Penerj.) Jakarta: Salemba Empat.

Tampubolon, K. (2018). Transfer Pricing Dan Cara Membuat TP Doc. Yogyakarta: Deepublish.

Tokan, P. R. (2016). Manajemen Penelitian Guru. Jakarta: Grasindo.

Wardoyo, T. H., Subiyakto, A., \& Argo, S. W. (2015). Pajak Terapan Brevet A\&B. Jakarta: Tax Sys (PT TAXSYS INDONESIA).

Zulfikar. (2016). Pengantar Pasar Modal dengan Pendekatan Statistika. Yogyakarta: Deepublish 
